\title{
A VIA RUPTURISTA: O MOVIMIENTO DE IZQUIERDA REVOLUCIONARIA E O GOVERNO DE SALVADOR ALLENDE (1970-1973)
}

\author{
THE RUPTURIST WAY: THE MOVIMIENTO DE IZQUIERDA \\ REVOLUCIONARIA AND SALVADOR ALLENDE'S \\ ADMINISTRATION (1970-1973)
}

DOI: http://dx.doi.org/10.15448/2178-3748.2016.1.22922

\author{
Maurício Marques Brum \\ Doutorando em História - UFRGS \\ mauribrum@gmail.com
}

\begin{abstract}
RESUMO: Fundado em 1965, o Movimiento de Izquierda Revolucionaria (MIR) foi a maior organização de esquerda do Chile a não integrar a Unidad Popular (UP), a ampla coalizão que levou o socialista Salvador Allende à Presidência da República em setembro de 1970. Visto como uma organização "extremista" pela direita e por setores moderados da esquerda, o MIR defendeu a necessidade de preparar o povo para um conflito armado contra as classes dominantes, mesmo durante o governo Allende. Sua posição, definida por Casals (2010) como a "via rupturista", contrariava a postura hegemônica da UP: o projeto político liderado por Salvador Allende propunha realizar uma transição ao socialismo através da "via sistêmica", isto é, seguindo os ritos democráticos e a legislação pré-existente. Este artigo analisa os posicionamentos do MIR durante o governo da UP, suas tentativas de radicalizar o restante da esquerda e suas discordâncias em relação aos partidos moderados, diferenças que acabariam persistindo até o golpe de Estado liderado por Augusto Pinochet em 11 de setembro de 1973.
\end{abstract}

PALAVRAS-CHAVE: Movimiento de Izquierda Revolucionaria (MIR), Salvador Allende, Unidad Popular (UP).

\begin{abstract}
Founded in 1965, the Movimiento de Izquierda Revolucionaria (MIR) was the biggest left-wing organization in Chile not to join the Unidad Popular (UP), the broad coalition that led the socialist Salvador Allende to the presidency in September 1970. Seen as an "extremist" movement by the right-wing parties and the moderate left, MIR championed the need to organize the people for an armed struggle against the ruling classes, even during the Allende administration. Its position, defined by Casals (2010) as the "rupturist way", contradicted UP's hegemonic posture: the political project led by Salvador Allende proposed to carry out a transition to socialism through the "systemic way", i.e., following the democratic rites and pre-existing legislation. This paper analyzes the positions backed by the MIR during the UP government, their attempts to radicalize the remainder of the Chilean leftists, and their disagreements in relation to the moderate parties differences that would remain until the coup led by Augusto Pinochet on September 11, 1973.
\end{abstract}

KEYWORDS: Revolutionary Left Movement (MIR), Salvador Allende, Popular Unity (UP).

\section{INTRODUÇÃO}

O Movimiento de Izquierda Revolucionaria (MIR) ocupa uma posição disputada na história da esquerda chilena. Fundado em 1965, foi a maior organização de esquerda do Chile 
a não integrar a Unidad Popular (UP), coalizão que levou o socialista Salvador Allende à Presidência da República em 1970. Dono de um discurso polêmico e inflamado, crítico às posturas que considerava "reformistas" do governo, o MIR permaneceria até a queda de Allende posicionado no exterior da UP - sem ser situação nem oposição, buscaria atuar "desde fora" no sentido de "radicalizar" os partidos governistas.

Temendo que o processo legalista representado pela UP jamais levasse a uma Revolução "verdadeira", o mirismo sustentaria a necessidade de se preparar para um enfrentamento armado, mesmo em tempos democráticos. Para os setores da esquerda moderada, o MIR era comparável aos Tupamaros e tachado de "extremista", numa tentativa de isolá-lo do governo (TORRES, 2012, p. 19). Mesmo sem realizar ações aparatosas como seu suposto "análogo" uruguaio, o MIR afirmou desde o início a busca pelo "derrocamiento del sistema capitalista" (MIR, 1965a), jamais descartando a luta armada para tal fim (MIR, $1965 b)$

Por suas ações, que contrariavam os limites legais dentro dos quais Allende prometera atuar, o MIR chegou a ser considerado pela CIA como "un brazo de acción encubierta" do governo, um órgão destinado a extrapolar a lei quando ela impedisse as mudanças almejadas (BASSO, 2013, p. 223). Com efeito, Allende chegou a contar com miristas em sua escolta presidencial. Essa proximidade seria usada depois entre as justificativas do golpe militar encabeçado por Pinochet em 1973, que alegava haver um plano para usar o grupo em um "autogolpe" que derrubasse o regime democrático vigente, implantando uma "ditadura popular" ainda com Allende na presidência (SECRETARÍA GENERAL DE GOBIERNO, 1973).

No entanto, a aproximação de Allende com o MIR também é defendida não como uma concordância com os pensamentos do grupo, mas como uma busca por evitar que a organização prejudicasse o governo. Já em novembro de 1971 os miristas haviam abandonado a escolta presidencial, precisamente por discordar de Allende (MONIZ BANDEIRA, 2008, p. 284). O grupo passou a ser visto com ainda mais reservas pela parte da UP que o considerava extremista. Max Marambio, que se desligou do MIR para seguir na escolta, relata que a organização havia esperado a derrota eleitoral da UP, interpretando que isso reforçaria a tese da luta armada como única alternativa para o povo chegar ao "poder real" (MARAMBIO, 2007, p. 69). 
O radicalismo do MIR seguiria sendo criticado pela esquerda "tradicional”, sobretudo após o golpe de Estado, quando as posições do grupo passariam a ser apontadas como uma das causas para a oposição temer o governo ao ponto de apoiar um levante militar. $\mathrm{O}$ movimento, contudo, permaneceu até ás vésperas do golpe em sua tentativa de atrair setores da UP para uma tática que levasse em consideração a opção das armas. Neste artigo, analiso os posicionamentos do mirismo durante o governo da UP, suas tentativas de radicalizar o restante da esquerda e as discordâncias em relação a ela, não superadas antes do golpe de 11 de setembro de 1973.

\section{AS LEITURAS DO MIRISMO APÓS A ELEIÇÃO DE ALLENDE}

Apesar de permanecer crítico ao governo durante todo o período em que Salvador Allende ocupou o assento presidencial no Palácio de La Moneda, o MIR nunca se constituiu como uma organização contrária a ele - procurava, desde fora, fazer com que as mudanças sociais fossem aprofundadas, mesmo que isso se desse à margem da institucionalidade. Seguir a legislação pré-existente, contudo, era uma das bandeiras do presidente (ALLENDE, 1998), e essa se converteria na principal discordância entre os miristas e a UP.

De todo modo, a posição do MIR em trabalhar com o governo é afirmada desde o momento em que a vitória de Allende se confirma, na madrugada de 4 de setembro de 1970 . Em "El MIR y el resultado electoral”, texto publicado na revista do movimento, Punto Final, pouco após o pleito, a organização manifesta sua satisfação com o triunfo da UP - mas deixa clara sua desconfiança com o modelo legalista, mantendo a crença no "conflito inevitável" que, mais cedo ou mais tarde, oporia o povo às classes dominantes:

La mayoría electoral de la izquierda [...] abre para todos los trabajadores un nuevo período histórico. Se han incorporado grandes y nuevos sectores del pueblo a la lucha por el socialismo, y el triunfo electoral a nivel da la conciencia de las masas entregó a éstas la sensación de victoria y de "derecho a gobernar", comprometidos detrás de un programa, lo que implica un proceso irreversible en las futuras formas de expresión de su aspiración a constituirse en poder. [...] creemos que como está formulado el programa de la UP, golpea algunos núcleos vitales del capitalismo como las empresas extranjeras, el capital financiero, el sector monopólico de la gran industria y el latifundio. Creemos también que si este programa es llevado a cabo, provocará una contraofensiva imperialista y burguesa que, sumada a las energías y aspiraciones que se librarán a nivel de masas, obligará a una rápida radicalización del proceso. Por ello, si bien el programa de la UP no es idéntico al nuestro, empujaremos y apoyaremos la realización de estas medidas (SECRETARIADO NACIONAL MIR, 1970, p. 4-6). 
Baseado em experiências anteriores do continente latino-americano, os dirigentes miristas continuavam o documento prenunciando a maneira como a tal "contraofensiva imperialista e burguesa" se daria: através da desestabilização social e econômica. Seria o pretexto, garantia o MIR, para os setores reacionários convocarem as Forças Armadas a fim de "restaurar a ordem":

Al parecer la estrategia predominante de la burguesía y el imperialismo consiste en permitir que Allende asuma, tratar de darle solo unos meses de gobierno, "amarrarlo" en la maraña del legalismo vigente, vigilar el cumplimiento de esos "amarres" por las Fuerzas Armadas y así tener la UP bajo la amenaza permanente de un golpe militar reaccionario, buscando así impedirle llevar a cabo sus planes fundamentales y resolver los problemas de las aspiraciones de las masas. Desencadenar al mismo tiempo la baja en la producción industrial, negarle la renegociación de la deuda externa, disminuir las siembras en los campos y de esta manera aumentar la inflación y la cesantía: se intenta desprestigiar así un gobierno UP y entonces, en base a los grupos de derecha creados en el intertanto, arrastrar las Fuerzas Armadas a "salvar la Patria", e impedir "el desorden y el caos"; y solo entonces derribar a Allende en condiciones políticas más favorables a ella (SECRETARIADO NACIONAL MIR, 1970, p. 9-10).

Acreditando que seguir no caminho legalista acabaria sendo precisamente a ruína de um governo popular, pois implicaria em negociar e ceder a setores ligados às oligarquias, o MIR nunca se daria por satisfeito com os avanços obtidos pela UP. Para a organização, era inviável fazer as mudanças necessárias seguindo os ritos democráticos, e seria preciso substituir o "reformismo" pela "revolução". Ter assumido o governo, argumentava o mirismo, era apenas atingir uma fração do poder real: as Forças Armadas, o Congresso e outras instituições fundamentias ainda estavam sob o mando de setores majoritariamente conservadores. "Para o MIR, a chegada da esquerda ao governo não resolvia o problema fundamental que toda revolução coloca, ou seja, o controle total do poder de Estado por parte dos trabalhadores. O objetivo proposto por este grupamento político [...] era o de trabalhar no sentido de criar - via mobilização de massas - uma alternativa de poder ao Estado burguês" (AGGIO, 2002, p. 51).

Essa maneira de encarar a realidade política chilena fazia o mirismo e os setores mais radicalizados da UP interpretarem que o processo revolucionário deveria ter "uma definição mais nítida", isto é, almejavam "[colocá-lo] no eixo da revolução proletária de corte insurrecional, mediante a lógica do acirramento das contradições de classe" (AGGIO, 2002, p. 37). Logo nos primeiros meses da administração, enquanto o governo intensificou a reforma agrária, concluiu a nacionalização das principais minas de cobre, estatizou grande parte do 
setor bancário e iniciou até mesmo a socialização de fábricas, ainda se acusava Allende de negociar demais com a oposição - crítica que não vinha apenas do mirismo. Apoiados pelo MIR, mas também por setores radicais do próprio Partido Socialista (PS) do presidente, alguns movimentos populares acusariam o governo de "reformismo", clamando pela aceleração do processo na direção de uma verdadeira "revolução" (MONIZ BANDEIRA, 2008, p. 264).

Em pouco tempo, ocupações de terrenos e plantas fabris começaram a ocorrer mesmo em locais que não eram contemplados pelas leis de socialização e de reforma agrária. Peter Winn (2010, p. 89) observa que "o momento certo, a sequência, o escopo e o controle dessa planejada revolução vinda de cima [do governo] foram desafiados e transformados pela erupção de uma imprevista, porém acelerada e profunda, "revolução vinda de baixo"'. Essa revolução vinda de baixo, promovida por trabalhadores, pobladores ${ }^{1}$ e camponeses, "cada vez mais divergia da revolução legalista e modulada vinda de cima, em um processo mais espontâneo e interativo das bases que não era facilmente controlado de cima" (WINN, 2010, p. 89).

A "revolução vinda de baixo", da qual fala Winn, encontrou grande vazão durante os dias de Allende, em parte porque os movimentos sociais passaram a atuar sem o medo de sofrer a mesma repressão que os havia esmagado em administrações anteriores, mesmo agindo à revelia da tática política empregada pelo governo. Ainda assim, vendo o risco de a situação se tornar ingovernável, o presidente continuou a buscar acordos com a oposição, ao mesmo tempo em que tentava domar os anseios das alas menos moderadas da esquerda: "Allende procurou refrear o açodamento com que tais correntes políticas intentavam apressar e aprofundar as mudanças, temendo que o processo da reforma agrária se deteriorasse e se tornasse incontrolável, com a ocupação violenta e ilegal de terras”, descreve Moniz Bandeira (2008, p. 265). Entretanto, "nos muros e paredes de Santiago apareciam frases chamando Allende de 'momio número uno', i. e., reacionário $\mathrm{n}^{\circ} 1$, pintadas por extremistas ou por elementos manipulados pela CIA, a fim de incitar a radicalização" (MONIZ BANDEIRA, 2008, p. 265).

O modo inflamado de atuar dos setores mais exaltados não era uma novidade, e se relacionava a um debate mais antigo travado no seio da esquerda chilena - uma discussão que

\footnotetext{
${ }^{1}$ Os pobladores, literalmente "povoadores", eram os pobres urbanos sem-teto, frequentemente diaristas sem emprego fixo, que desde o final dos anos 1950 passaram a se organizar em ocupações irregulares de terrenos baldios, onde erguiam suas casas e formavam as chamadas poblaciones, espécies de favelas.
}

Oficina do Historiador, Porto Alegre, EDIPUCRS, v. 9, n. 1, jan./jun. 2016, 
precedia o nascimento do próprio MIR, ainda que estivesse diretamente ligada a ele. Tratavase da disputa entre o que Marcelo Casals diferencia entre a "via sistêmica" e a "via rupturista" no Chile: a primeira defendendo "la participación institucional como camino revolucionario adecuado a la realidad nacional", ao passo que a segunda construiu planos de ação que tendiam à "destrucción del orden constitucional como condición necesaria para el sistema socialista" (CASALS, 2010, p. 10). No final dos anos 50, quando Salvador Allende se torna um candidato viável para a esquerda ${ }^{2}$ e, pouquíssimo tempo depois, quando a Revolução Cubana triunfa pelas armas, os dois lados desse debate ganham argumentos fundamentais na discussão sobre o melhor caminho para uma transição socialista no Chile.

Miguel Enríquez, secretário-geral do MIR, insistiria sempre na impossibilidade de negociar com os principais partidos que faziam a oposição a Allende - o Partido Nacional (PN) e o Partido Democrata Cristão (PDC). Ao longo de 1973, Enríquez repetiria que essas siglas sempre acenavam com supostos acordos, os quais na realidade nunca se concretizariam. Seria apenas uma forma de conquistar os "sectores más vacilantes de la Izquierda, sembrando en ellos ilusiones en acuerdos posibles” (ENRÍQUEZ, 17 jul. 1973, p. 264).

Manifestando o posicionamento oficial de sua organização, Enríquez não via problemas nas acusações de que o MIR atuava à margem da legalidade, pois no entendimento do mirismo era o próprio regime legal que estava errado. O PN e o PDC, dizia, escondiam-se atrás de uma "falsa democracia" para marginalizar a esquerda revolucionária e proteger seus interesses de classe: "Defienden esa democracia que mata por hambre y miseria a millones en el mundo entero. Defienden esa democracia que no es democracia, sino dictadura burguesa y patronal" (ENRÍQUEZ, 17 jul. 1973, p. 264). Insistindo na defesa da via armada e da ação direta, o secretário-geral do MIR negava o radicalismo ou a ilegalidade de suas propostas:

Dirán los reaccionarios que esto es transgredir las leyes, la Constitución y el Derecho. Sí que lo es. Las constituciones expresan intereses de clase y correlaciones de fuerza. Aquí en Chile la clase obrera está levantando en la

\footnotetext{
${ }^{2}$ Salvador Allende concorreu à presidência pela primeira vez em 1952, à frente do Partido Socialista. Foi o candidato menos votado entre os quatro concorrentes, com apenas 5,45\% do eleitorado. Como observa seu biógrafo, Jesús Manuel Martínez (2009, p. 214), a ousadia de concorrer mesmo nas precárias condições da época (entre outras questões, o Partido Comunista estava clandestino e não podia apoiá-lo oficialmente) não trouxe votos imediatos, mas permitiu a Allende se tornar o nome forte de todas as coalizões de esquerda que viessem a se formar nas próximas duas décadas, indicado como presidenciável nos três pleitos seguintes (1958, 1964 e 1970, quando é eleito). Mas são as eleições de 1958 as decisivas para que a "via sistêmica", dentro da legalidade democrática, siga sendo considerada seriamente por tanto tempo pela esquerda: nesse pleito, a possibilidade de uma vitória da esquerda aparece de forma clara, e os maus resultados de 1952 são substituídos por um estreito segundo lugar - Salvador Allende recebe apenas 33,5 mil votos a menos que o vencedor, o conservador Jorge Alessandri.
} 
práctica sus propias leyes y la Constitución tendrá que cambiar en favor del pueblo (ENRÍQUEZ, 17 jul. 1973, p. 265).

Desde a sua fundação, tanto na prática quanto (principalmente ${ }^{3}$ ) no discurso, o MIR atuou na banda "rupturista". Para o mirismo, a dicotomia entre sistema e ruptura era mais bem definida em termos que separavam os "reformistas" dos "revolucionários". Essa posição, como se vê, não mudaria até 1973, já nas vésperas do golpe. O que se modificaria, sobretudo após a vitória de Allende, seria a posição que o MIR adotaria em relação ao restante da esquerda: tentando não mais se apartar tão claramente dela, passaria a buscar a criação de laços de proximidade com os setores mais radicalizados da UP, na tentativa de uma "unidade" da esquerda revolucionária que superasse a fase reformista - ou "pré-revolucionária", nos termos leninistas que a organização usava para definir o momento (TORRES, 2012, p. 171). Tal postura é demonstrada por um discurso proferido por Miguel Enríquez em março de 1973:

[...] cuando los reformistas dicen que lo que persiguen algunos sectores que nosotros agrupamos en lo que llamamos la izquierda revolucionaria es dividir la UP y a la clase obrera, la verdad es que no es así. Los únicos que están dividiendo organizaciones hoy día son los reformistas. Es necesario que se entienda definitivamente que hay dos políticas en la izquierda y esas dos políticas tienen que expresarse en el terreno de la lucha ideológica y tienen el derecho y el deber de hacerlo. Lo importante es hacerlo sobre la base de no buscar la división, sino fundalmentalmente imponer una política, hacer que predomine una política sobre la otra, tal como hoy ha predominado la reformista, imponer en el futuro que se pueda predominar la revolucionaria. Se trata de levantar la unidad de los revolucionarios (ENRÍQUEZ, 10 mar. 1973, p. 228).

\section{OS DESACORDOS COM A UNIDAD POPULAR: A VISÃO COMUNISTA}

Da sua concepção até o golpe - e mesmo depois dele -, o relacionamento mais tortuoso do MIR com as outras siglas de esquerda se daria frente ao Partido Comunista Chileno (PCCh). Assumidamente ligado ao PC da União Soviética e recém-saído da experiência de haver permanecido na clandestinidade por dez anos ${ }^{4}$, o PCCh vinha seguindo a

\footnotetext{
${ }^{3}$ Embora tenha realizado assaltos a banco, a que chamou "expropriações", nos anos anteriores à vitória de Salvador Allende, o MIR não realizou qualquer ação armada notória durante o período democrático. Seu discurso e, mesmo, sua estética guerrilheira frequentemente acabavam sendo mais uma estratégia de diferenciação da esquerda "moderada" do que efetivamente algo que se verificou na prática, ao menos antes do golpe (TORRES, 2012, p. 175).

${ }_{4}$ O Partido Comunista Chileno foi declarado ilegal pela Lei 8.987, de 3 de setembro de 1948, intitulada oficialmente "Ley de Defensa Permanente de la Democracia", e conhecida pela esquerda como "Ley Maldita". A lei colocou na clandestinidade as organizações comunistas e, através da cassação de registros eleitorais de seus militantes, derrubou de seus cargos todos os políticos eleitos pelo PCCh. Foi aprovada durante o governo do presidente González Videla (1946-1952), que havia sido eleito com apoio dos comunistas - o que lhe rendeu a
} 
linha então defendida por Moscou e havia adotado já no início da década de 1960 a opção por buscar o poder dentro da via institucional. Para Luis Corvalán, secretário-geral do Partido, o debate entre "ruptura" e "sistema" era resolvido na medida em que uma revolução não precisaria ser necessariamente violenta: ainda em 1961, “[Corvalán corrigió] a los que hablaban indistintamente de 'vía violenta' y 'vía revolucionaria', puesto que el camino pacífico, dentro de la concepción comunista, presentaba también un alto potencial revolucionario, en la medida que trataba de alcanzar con diferentes medios el mismo objetivo" (CASALS, 2010, p. 64).

O Partido Comunista também acusava o mirismo de ser "pequeno-burguês" e fazer uma interpretação errônea dos caminhos para a Revolução, e isso não apenas pelas discordâncias práticas durante os dias de Salvador Allende: algumas das organizações que levaram à fundação do MIR em 1965, como a Vanguardia Revolucionaria Marxista (VRM), tinham em suas fileiras trotskitas expulsos do PCCh alguns anos antes (CASALS, 2010, p. 107). De fato, embora a linha trotskista acabasse por ser rapidamente alheada também dentro do $\mathrm{MIR}^{5}$, sua influência foi bastante sentida nos anos iniciais do movimento, aparecendo de forma mais vocal na "Declaración de Principios" da organização, que o mirismo acabaria mantando mesmo após a mudança de direção (TORRES, 2012, p. 93).

O MIR devia seu nascimento, em boa medida, à derrota de Allende nas eleições de 1964: após o cenário animador apresentado seis anos antes, naquele pleito Allende acabaria vendo seu adversário fazer a maior votação da história chilena até então - temendo um triunfo da esquerda, os partidos conservadores não apresentaram candidato próprio e apoiaram o centrista Eduardo Frei, do PDC, que contou com financiamento estadunidense em sua campanha e amealhou mais de 56\% do eleitorado, contra 39\% de Allende (GARCÉS, 1993, p. 61). A derrota, num momento em que a esquerda tinha grandes expectativas de vencer, fez a discussão entre eleições e armas redobrar sua força. E, se esse era um debate que as lideranças de PCCh e PS domavam, mantendo um discurso revolucionário e uma prática que seguia

pecha de "traidor", eternizada por Pablo Neruda (então senador pelo PCCh, que teve seu mandato cassado pela lei e precisou se exilar) em diversos versos de seu Canto General, livro publicado em seu exílio, no México, em 1950. A “Ley Maldita” só seria derrogada em 6 de agosto de 1958, quase uma década após entrar em vigor.

${ }^{5}$ Isso acontece após um grupo de jovens saídos da Universidad de Concepción, liderado por Miguel Enríquez, vencer as eleições para o Comitê Central em 1967. Nessa época, alguns dos referenciais da época da fundação do MIR abandonam a organização. Enríquez passará a dominar o MIR, e não deixará de fazê-lo antes de sua morte, em 1974. Diante da diáspora dos velhos miristas, Enríquez passará a buscar "assessoria" de cientistas sociais, chilenos e estrangeiros, alguns dos quais chegam a colaborar estreitamente com a direção do MIR - dois casos notórios são o do alemão André Gunder Frank e o do brasileiro Ruy Mauro Marini (AMORÓS, 2015, p. 84 e 93). 
participando de eleições, muitos jovens militantes tentaram ir por outro lado: "mientras los dos grandes partidos alternaban con naturalidad entre el discurso crítico de lo electoral y la apasionada participación em las campañas, los pequeños partidos que formarán el MIR parecían determinados a eliminar definitivamente la vía electoral de su agenda" (PALIERAKI, 2014, p. 84).

Diferentes gerações de ex-militantes de PS e PCCh, bem como de dirigentes estudantis e sindicais, uniram-se para formar o MIR em 1965. A nova organização procurou se diferenciar da política partidária existente até na escolha do nome ("Movimento" e não "Partido" $)$. Apesar da variedade de correntes presentes no ato fundacional, desde muito cedo seriam os jovens universitários que tomariam a dianteira da organização, com a chegada de Miguel Enríquez ao posto de secretário-geral em 1967.

No diagnóstico de Osvaldo Torres, o que ocorre entre a fundação do MIR e o ano de 1969 - quando o IV Congresso da organização é cancelado e o grupo de Miguel Enríquez acaba permanecendo no poder sem passar por novas eleições internas - será uma mudança da hegemonia teórica de matriz trotskista, que pouco a pouco é superada e substituída por outra com “enfoques más contemporáneos del marxismo" (TORRES, 2012, p. 95). ${ }^{7}$

Mas a saída do MIR de militantes trotskistas e de outros que haviam sido expulsos pelo PCCh não melhorou as relações entre os dois partidos: permaneciam as acusações de que o MIR era uma organização "aventureira", "pequeno-burguesa" e desconectada da realidade (CASALS, 2010, p. 186-187). Um movimento por vezes tão crítico à UP que, na leitura comunista, acabava por fazer o "jogo da direita" - pensamento explicitado até mesmo por Pablo Neruda, que faz uma referência ao mirismo em sua Incitación al Nixonicidio y alabanza de la Revolución Chilena, livro panfletário publicado no início de 1973, quando cita a revista Punto Final, na qual o MIR expunha rotineiramente suas posições:

$$
\begin{aligned}
& \text { "Pec" y "Punto Final", que marchan } \\
& \text { juntos } \\
& \text { como va el explosivo con la mecha } \\
& \text { y se confunden en un mismo punto } \\
& \text { ultras de izquierda y ultras de derecha, }
\end{aligned}
$$

\footnotetext{
${ }^{6}$ Eugenia Palieraki (2014, p. 91-92) argumenta que a opção por "Movimento" não era apenas com o objetivo de exibir uma diferença em relação às siglas "tradicionais": também remetia às origens sindicais do MIR, "ya que el sindicalismo siempre tuvo una certa desconfianza en los partidos"; devia-se, igualmente, a uma referência à ideia dos "movimentos sociais" de base; e, por fim, remetia ao contexto político da América Latina na época, com o termo "Movimiento" já tendo sido utilizado pelos revolucionários cubanos (o "Movimiento 26 de Julio"), e inclusive precedentes da sigla MIR adotada por organizações na Bolívia, no Peru e na Venezuela.

${ }^{7}$ O próprio Miguel Enríquez, analisando a evolução do MIR no período, diria: "Nacimos en 1965, existimos realmente desde 1967, actuamos desde 1969" (ENRÍQUEZ, dez. 1973, p. 313. Grifo meu).
} 
duros de la derecha y de la izquierda, trabajan juntos en la misma brecha para que la victoria conseguida por un pueblo que lucha y que recuerda (el cobre, el pueblo, la paz y la vida), todo lo manden ellos a la mierda. Y así están juntos en el mismo cielo los locos de derecha y los locuelos (NERUDA, 1974, p. 85). ${ }^{8}$

\title{
PEQUENO-BURGUESES E REVOLUCIONÁRIOS
}

O minúsculo Partido Comunista Revolucionário (PCR), uma dissidência do PCCh formada em 1967 que não chegaria a ter qualquer relevância política, talvez tenha sido a organização que expôs de forma mais clara a contrariedade que muitos partidos mantinham em relação ao discurso do MIR: o mirismo, dizia o PCR, era fruto simplesmente de "tendências esquerdistas" que se desenvolviam em "meios pequeno-burgueses" e, ao defender as armas sem pesar as consequências para os trabalhadores, trazia apenas formulações "vagas, dispersas, incoerentes e contraditórias". O manifesto afirmava:

\begin{abstract}
Debemos confesar honestamente que no nos interesa dilapidar nuestros esfuerzos, enfrascándonos en una estéril polémica con el MIR, por la ninguna significación que este grupo tiene entre la clase obrera. Una actividad de este tipo, sólo alegraría a los pequeño-burgueses que hacen la revolución detrás de los escritorios y deliran vaciando sus "ímpetos revolucionarios" entre las teclas de la máquina de escribir. [...] Se llenan de satisfacción con su "heroísmo" y con el eco altisonante de su palabrería "ultrarrevolucionaria". Sin el apremio de liberarse en serio de una explotación que sólo sufren levemente y con un sentido del honor propio de los caballeros feudales, que cargaban en forma rectilínea y a ojos cerrados, consideran indigno que los obreros busquen alianzas transitorias y se propongan derrotar a sus poderosos enemigos por partes, es decir, por etapas (PARTIDO COMUNISTA REVOLUCIONARIO, 1967, p. 293-295).
\end{abstract}

Enríquez que, como os demais líderes do MIR, provinha da classe média, defendia-se argumentando que suas origens sociais não se diferiam das de outros dirigentes da esquerda: "La izquierda tradicional solo puede echar en cara al MIR la juventud de sus dirigentes. Porque la mayoría de la dirección de esos partidos es también pequeño-burguesa, aunque más vieja que la nuestra" (ENRÍQUEZ, 23 abr. 1968, p. 3). Além de citar Castro, Mao e o "Che" como revolucionários saídos de um meio pequeno-burguês, o líder do MIR ainda argumentava que sua organização vinha se esforçando para mudar a composição de seus

\footnotetext{
${ }^{8}$ A "PEC" (sigla para "Política, Economía y Cultura"), outra publicação mencionada no primeiro verso do poema, mantinha posições de direita.
} 
quadros, insinuando que os outros partidos não agiam com a mesma ênfase nesse sentido: "Desde 1966 viene cambiando progresivamente la composición de clases em nuestra organización y hoy el panorama es distinto. Surgen cuadros obreros y de pobladores, como asimismo estamos actuando con relativa eficacia en el frente campesino" (ENRÍQUEZ, 23 abr. 1968, p. 3).

O MIR, efetivamente, procurou criar diferentes níveis de atuação, através das "frentes intermediárias": passou a contar com o Movimiento de Campesinos Revolucionarios (MCR), que lutava pela reforma agrária; o Movimiento de Pobladores Revolucionarios (MPR), que atuava nas ocupações urbanas das poblaciones; a Frente de Trabajadores Revolucionarios (FTR), ligada ao movimento sindical e importante órgão de articulação dos chamados "cordões industriais", além de dois diferentes braços no movimento estudantil, o Movimiento Universitario de Izquierda (MUI) e a Frente de Estudiantes Revolucionarios (FER).

A atenção especial do MIR aos pobres rurais e urbanos renderia frutos, principalmente entre os movimentos de luta por terra e moradia. Em 1970, a fundação do "Campamento 26 de Enero", a primeira grande población controlada pelo MPR em Santiago, foi interpretada pelo MIR como um "embrión del frente de masas que movilizaría a los pobladores". Significava, também, que "la presencia pública del mirismo ya no se circunscribía solo al movimiento estudiantil y al impacto periodístico de sus espectaculares acciones directas" (AMORÓS, 2015, p. 119). Mas o MIR, que em suas várias frentes talvez tenha chegado a mais de 40 mil membros no ano do golpe ${ }^{9}$, sempre teve sua maior força entre os estudantes universitários - mesmo as organizações destinadas a trabalhar em outros setores, como as poblaciones, tinham muitas lideranças saídas do movimento estudantil (TORRES, 2012, p. 111).

O MIR exercia um grande apelo sobre a juventude. Para muitos, "el MIR representaba la única vía de ingreso a la política y a las luchas sociales” (RIVAS, 2007, p. 19). Evidentemente, nas universidades esse caminho também poderia ser aberto pelas alas jovens das siglas da UP, como a Juventude Socialista ou a Comunista, que não apenas eram menos estigmatizadas do que a chamada "ultraesquerda", como tinham também a vantagem de integrar o governo. Para Patricio Rivas, a grande diferença entre os partidos "tradicionais" e o

\footnotetext{
${ }^{9}$ A maior parte dos registros do movimento se perdeu na repressão, quando a direção mirista foi dizimada. Esse número é uma estimativa - talvez exagerada - de Andrés Pascal Allende, sobrinho do presidente Salvador Allende e um dos líderes do MIR à época (cf. PASCAL ALLENDE, 2003, p. 70). Uma estimativa mais conservadora situa em torno de 10 mil o número de membros do MIR em 1973 (ANDERSON; SLOAN, 2009, p. 447).
} 
Movimiento de Izquierda Revolucionaria estaria na composição da cúpula deste último: "Había un rasgo que lo hacía aún más atractivo que otras organizaciones de Izquierda. El MIR era dirigido por jóvenes y eso impresionaba" (RIVAS, 2007, p. 19).

A presença de jovens nas posições mais importantes - Miguel Enríquez tinha apenas 23 anos quando se tornou secretário-geral, em 1967 - e o discurso abertamente em prol das armas mesmo sob Allende também contribuíam para exercer um fascínio particular para uma geração que formou seu pensamento de esquerda na década seguinte à Revolução Cubana. A impressão era de que "aunque en sus comienzos eran más Mao que Castro, los jóvenes dirigentes del MIR parecían llamados, aunque solo fuera por motivos generacionales, a administrar en Chile el inmenso prestigio de la revolución cubana" (MARTÍNEZ, 2009, p. 286).

Era significativo que, embora tendo grande penetração nesses meios e em mobilizações de massa que atuavam à revelia do governo - nos casos dos camponeses e dos pobladores -, o MIR jamais tenha conseguido atingir representatividade em instituições mais normatizadas: a política partidária e o movimento sindical. Se no caso da primeira isso se dava por opção estratégica, não participando de eleições, em relação ao segundo era principalmente pelo fato de a FTR jamais ter alcançado a penetração que o mirismo gostaria.

A diferença do peso político entre os operários ficava evidente em momentos como as eleições para o Conselho Diretivo Nacional da Central Unitaria de Trabajadores (CUT), a maior central sindical do Chile, celebrada em 1972: dos 560.240 votos emitidos para escolher 55 conselheiros, menos de $2 \%$ (exatamente 10.192 cédulas) foram para a lista da FTR, que elegeu apenas um conselheiro (Alejandro Alarcón, dirigente do sindicato da empresa têxtil estatizada Bellavista-Tomé), ao passo que o Partido Comunista e o Partido Socialista, juntos, fizeram 34 conselheiros e mais da metade (321.208) dos votos. Mesmo o PDC, que nunca se considerou de esquerda, tinha uma representação significativa, conquistando 16 assentos no conselho para um total de 147.531 votos (AMORÓs, 2015, p. 188).

\section{TENTATIVAS DE APROXIMAÇÃO COM O GOVERNO}

O MIR, no entanto, não estava tão isolado do restante da esquerda quanto as posições comunistas pareceriam indicar. Enquanto o PCCh muitas vezes se recusava até mesmo a participar de eventos nos quais Miguel Enríquez ou outro representante mirista era convidado 
a falar ${ }^{10}$, a outra grande sigla da UP tinha amplos setores simpáticos ao posicionamento do MIR. De fato, se o mirismo pôde crescer a ponto de se tornar um ator político importante (mesmo sem representatividade parlamentar e com um peso quase nulo entre as lideranças sindicais), muito se devia à relativa abertura que as demais siglas da coalizão governista, sobretudo o Partido Socialista, tiveram em relação ao movimento que o PCCh tachava de extremista. Mesmo antes da eleição de Allende, quando o governo do democrata-cristão Eduardo Frei colocou o MIR brevemente na clandestinidade, essas relações apareceram:

Hubo también otro factor importante en aquel tiempo, que además ayudó a los dirigentes del MIR a sortear las dificultades de la clandestinidad: su vinculación con sectores de la izquierda "tradicional", principalmente del Partido Socialista. La influencia de la Revolución Cubana, la decepción ante la derrota de 1964, la sonora radicalización del Partido Socialista [...] y también las relaciones políticas y personales ayudaron a tejer esos estrechos vínculos, a crear un "colchón político-social" dentro de la elite política (AMORÓS, 2015, p. 113-114).

Assim, enquanto o MIR sustentava, mesmo em pleno governo da UP, a necessidade de se preparar para um confronto armado contra as classes dominantes, importantes setores do PS continuavam a se articular de forma semelhante ao grupo que o PCCh tentava marginalizar como uma "exceção" dentro da esquerda. Como argumenta Eugenia Palieraki, a visão retrospectiva de que a via armada era apenas "asunto de los extremos" ignora as dimensões que o debate tinha na época. Se é verdade que amplos setores da UP continuaram legalistas até o final, o que inclusive se verificou pela inexistência de frentes militarizadas, levando a uma quase nula resistência armada ao golpe, é igualmente verdadeiro que não apenas os “extremistas" cogitaram a necessidade das armas: "Cuando la revolución parecía esperar a la vuelta de la esquina, el dilema entre vía armada y vía electoral se planteaba en todas las organizaciones con mayor o menor intensidad y persistencia” (PALIERAKI, 2008, p. 4).

Importantes na aproximação do PS com o MIR foram as resoluções tiradas pelo Congresso socialista de 1967, na cidade de Chillán, quando o discurso hegemônico do partido se radicalizou e se distanciou ainda mais dos comunistas. Na prática, as posturas defendidas nesse encontro legitimaram a luta armada como caminho aceitável na visão do PS (ainda que

\footnotetext{
${ }^{10}$ Um exemplo foi o fórum organizado pelo Secretariado Nacional de Cristianos por el Socialismo, em 1972, quando os representantes do Partido Comunista se retiraram do debate em meio à fala de Miguel Enríquez. O secretário-geral do MIR respondeu à situação asperamente, declarando que "el reformismo [...] confunde con mucha facilidad al enemigo principal", acrescentando que "los compañeros comunistas no se retiran de los foros de TV con los nacionales [del PN] y los DC, pero siempre en todo foro, estando el MIR, se retiran porque siempre hay algún hecho que 'ofende al partido de la clase obrera' y 'ofende al gobierno"” (ENRÍQUEZ, nov. 1972, p. 204).
} 
não o único), e mesmo um nome como o então senador Salvador Allende, que tentou fazer uma intervenção para contrariar a postura majoritária e defender a via institucional, saiu do púlpito vaiado pelos próprios correligionários (CASALS, 2010, p. 180-181). Em Chillán, a maioria dos delegados vindos de todos os cantos do país aprovou posicionamentos como os defendidos naquele mesmo ano pelo ex-senador Alejandro Chelén, para quem o PS não tinha que firmar "compromisos con partidos que se dicen 'progresistas' y de izquierda, cuyas filas se nutren de banqueros, empresarios, latifundistas, entroncados de una u otra manera al capitalismo monopolista", mesmo se isso parecesse necessário por questões eleitorais ou de governabilidade (CHELÉN apud CASALS, 2010, p. 172).

Chelén citava, como exemplos de partidos com uma falsa roupagem progressista, o Radical e o Democrata Cristão. É sinal expressivo da força de Allende dentro do PS que, apesar das resoluções de Chillán, seu partido tenha participado das eleições de 1970 numa coligação que incluía esse mesmo Partido Radical (PR) acusado de estar ao lado do "capitalismo monopolista". ${ }^{11}$ Além disso, seria precisamente com o PDC - o outro atacado por Chelén - que o governo negociaria até o fim, tentando uma saída para a crise política que evitasse o golpe. Mas Allende se isolaria cada vez mais do restante do PS, e tais posturas acabaram podendo ser levadas a cabo dentro da UP não tanto pela anuência dos socialistas cada vez mais radicalizados, mas pela insistência dos comunistas em buscar soluções democráticas, através da via legal.

O peso de posturas menos moderadas do PS havia se manifestado, por exemplo, nas primárias da sigla, quando a escolha de Allende como candidato à presidência se deu com constrangimento e por preferência de uma minoria - a reunião de cúpula do PS teve mais abstenções do que votos a seu favor, num resultado de 13 a 12 (GONZÁLEZ, 2012, p. 51). A longa frustração de Allende com os entraves impostos pelo próprio partido à sua posição apareceria na manhã de 11 de setembro de 1973, com o golpe em andamento, quando o dirigente socialista Hernán del Canto passou por La Moneda pedindo orientações ao

\footnotetext{
${ }^{11}$ O PR havia governado o país ao lado de comunistas e socialistas em décadas anteriores. Juntos, chegaram à presidência pela primeira vez em 1938, com Pedro Aguirre Cerda, coligados dentro da chamada Frente Popular. Na ocasião, porém, o PR era a agremiação política mais importante do país. O peso do partido seguiu forte nos dois pleitos seguintes: em 1941, após a morte de Aguirre Cerda no cargo, elegeram Juan Antonío Ríos. Quando este também faleceu na presidência, em 1945, o Partido Radical voltou a fazer um mandatário - Gabriel González Videla, que cumpriu todo o seu termo até 1952. Nessas eleições, a esquerda "tradicional” manteve seu apoio em maior ou menor medida. Uma grave ruptura ocorreu em 1948, ano em que González Videla assinou a "Ley Maldita", colocando o PCCh na ilegalidade (cf. AGGIO, 1999). Em 1970, quando o Partido Radical se reaproximou de socialistas e comunistas para compor a UP, sua importância no cenário político já era muito menor - com votações inferiores tanto ao PCCh quanto ao PS, a sigla protagonista nos tempos da Frente Popular teve agora um peso reduzido nas políticas da nova Unidad Popular (WINN, 2010, p. 50-51).
} 
presidente e ouviu a dura resposta: "Eu sei qual é o meu lugar e o que tenho que fazer. [...] Nunca antes pediram minha opinião. Por que me a pedem agora? Vocês, que tanto alardearam, devem saber o que têm que fazer. Eu soube desde o começo qual era meu dever" (GARCÉS, 1993, p. 324).

Antes e depois da vitória de Salvador Allende, o PS frequentemente sustentou posicionamentos similares aos do mirismo, muitas vezes à revelia do próprio presidente ou, mesmo, dos comunistas, seus aliados históricos. Em 1968, por exemplo, tanto o PS quanto o MIR criticaram a invasão soviética à Tchecoslováquia - encerrando a chamada "Primavera de Praga" -, ao passo que os comunistas a defenderam de forma veemente (TORRES, 2012, p. 130-131). Setores do Movimiento de Acción Popular Unitaria (MAPU) e da Izquierda Cristiana (IC) também se aproximariam decididamente do MIR durante a administração de Salvador Allende, mas nenhum deles tinha o peso dos socialistas dentro da UP. A ala menos moderada do PS não apenas continuou a estreitar laços com o mirismo como trabalhou ativamente para reduzir a resistência da coalizão governista às posturas e ações da organização liderada por Miguel Enríquez. Em fevereiro de 1972, após uma reunião da Unidad Popular em El Arrayán, um documento interno dos socialistas festejava que a declaração divulgada ao fim do encontro tinha um tom conciliatório: "se impone un estilo fraterno y claramente autocrítico en la declaración. No hay ningún ataque al MIR en todo el documento; es decir, se logró lo que buscaba el PS" (PARTIDO SOCIALISTA, 1972, p. 1997. Grifado no original).

Ao mesmo tempo, registrava-se uma aproximação ainda maior de setores do Partido Socialista (e da Izquierda Cristiana, uma dissidência do PDC que passou a integrar a Unidad Popular) em relação às posições defendidas pelas lideranças do MIR. Já em janeiro de 1973, citando nominalmente a presença de líderes do PS e da IC em um comício mirista celebrado no Teatro Caupolicán, o secretário-geral Miguel Enríquez comentou:

Los reaccionarios se preparan para caerle encima al pueblo y arremeter contra sus conquistas. Pero hoy no estamos en octubre. Se han creado nuevas condiciones que nos permiten afirmar que el pueblo puede triunfar en las batallas futuras. La masividad y combatividad de este acto ya lo está probando. La asistencia de dirigentes nacionales de otros partidos de la izquierda, nos señala también que una nueva situación comienza a ganar terreno entre las masas y las fuerzas políticas de la izquierda. Por eso valoramos la presencia a este acto del compañero Carlos Altamirano, Secretario General del Partido Socialista, del compañero Bosco Parra, Secretario General de la Organización de Izquierda Cristiana. Sabemos que no comparten todas nuestras posiciones pero tenemos coincidencias en 
muchas cuestiones importantes. Su asistencia a este acto es un paso más en el largo camino para unir a los revolucionarios (ENRÍQUEZ, 12 jan. 1973, p. 208).

Esse "longo caminho para unir os revolucionários" era também tortuoso, com diversos desacordos a cada ponto, e tentar percorrê-lo seguiria sendo uma das principais táticas do MIR nos meses seguintes. O discurso de janeiro de 1973 era especialmente significativo, não apenas pela presença de líderes de partidos da UP em um evento do MIR: também marcava a única vez em toda a trajetória do mirismo que a organização chamou seus militantes a participar nas eleições, incentivando votos em candidatos do PS e da IC no pleito legislativo que ocorreria no mês de março. Nessa época, desenvolveu-se no interior do mirismo a ideia de “crear el 'Frente Único' con la Unidad Popular para contener el golpe” (TORRES, 2012, p. 174).

O ensaio de aproximação dá início a uma fase em que o MIR tentará ganhar ainda mais proeminência dentro da esquerda, com a intenção de superar definitivamente o "reformismo" e atrair cada vez mais militantes da UP para a sua tática. Para Pedro Naranjo, o segundo trimestre de 1973 é quando o MIR “comienza a disputar efectivamente [...] la conducción política de las masas al reformismo, estableciendo con ello y para ello nexos cada vez más sólidos con los sectores más avanzados de la Unidad Popular"; isso, no entanto, "marca solo una tendencia que no llegó jamás a generalizarse o a tener un peso capaz de alterar el rumbo de la política nacional" (NARANJO, 2004, p. 25).

Essa incapacidade de mudar a posição majoritária da UP, de seguir no caminho legalista (que implicava em buscar um acordo com a oposição) começa a ficar bem clara já no mês de julho daquele ano. Em sua famosa fala no Teatro Caupolicán, no dia 17, Miguel Enríquez lamenta que - apesar das aproximações com setores do PS e da IC - importantes setores governistas ainda ignoravam o projeto da "esquerda revolucionária": "hay también otros en la izquierda que han pretendido cuestionar el derecho del MIR a proponer una táctica a las masas" (ENRÍQUEZ, 17 jul. 1973, p. 261). O secretário-geral do MIR então prossegue, insistindo na necessidade de pegar em armas e de adotar uma tática que priorize a ação direta. Mas o tom que tentava conquistar membros da UP para o seu pensamento já começava a desaparecer: o MIR seguiria tal tática, bradava Enríquez, "les guste o no les guste a las clases patronales y a los vacilantes” (ENRÍQUEZ, 17 jul. 1973, p. 261).

\section{A DERROTA DA ESQUERDA CHILENA}


A explícita hostilidade do discurso de 17 de julho de 1973 representava a constatação do insuficiente avanço do MIR no sentido de atrair outras militâncias para um projeto armado. Colocada a UP diante da radicalização e do diálogo com a oposição, foram os defensores deste último setor, liderado por Allende e disposto a negociar com o PDC, que mostrariam mais força, persistindo nas alternativas constitucionais até o final. Como os acontecimentos de 11 de setembro demonstrariam, aqueles a quem Enríquez chamava "vacilantes" seguiriam em seu próprio caminho, acreditando na legalidade política e institucional, e o mirismo ficaria praticamente sozinho em sua tática de resistência por meio da ação popular direta.

Essas diferenças persistiriam no próprio dia do golpe, como demonstra a significativa reunião com líderes de PS, PCCh e MIR na fábrica Indumet, em Santiago, na manhã do 11 de setembro: "El Golpe ya estaba en desarrollo y esa reunión era un último y desesperado intento por actuar unidos”, interpreta Ignacio Vidaurrázaga (2013, p. 96). Patricio Rivas, por sua vez, argumenta que desde pelo menos o Tancazo $^{12}$ o mirismo já tinha definido que atuaria ao lado da UP na eventualidade de um golpe: "Mucho tiempo antes el MIR había tomado la decisión de enfrentar una insurrección militar junto a todos los partidos que apoyaban a la Unidad Popular" (RIVAS, 2007, p. 38). Nem todos, contudo, concordavam com a maneira de exercer essa resistência. Na Indumet, novamente, não se chegou a um acordo: "los comunistas presentes no están a favor de la resistencia armada: 'hay que aguardar, los militares no se atreverán a cerrar el Congreso y la lucha deberá continuar desde allí’” (CASTILLO, 1999, p. 25).

Mas nem a organização de milícias populares chegou a se efetivar, nem o Congresso permaneceu aberto. A via democrática havia sido derrotada e a opção armada, também: apesar de seu discurso, o MIR se revelaria escassamente preparado para o confronto que tanto antecipou. Miguel Enríquez, naquela reunião, avisou que precisaria de algumas horas para reunir um contingente de apenas quatrocentos militantes treinados para combater, e mesmo frente a esse pequeno número só haveria armas e munição suficientes para cinquenta deles realizarem uma resistência minimamente eficaz (VIDAURRÁZAGA, 2013, p. 97). Sem acordos relevantes na Indumet, cada organização seguiria seu rumo e, independentemente da tática, todas se deparariam com a repressão, a clandestinidade, o exílio ou a morte.

Nas mais de quadro décadas desde o golpe de Estado no Chile, o discurso do MIR e as alternativas representadas pela organização têm sido sistematicamente excluídas de uma

\footnotetext{
${ }^{12}$ Tentativa de golpe militar frustrada ocorrida em 29 de junho de 1973.
} 
narrativa mais ampla da esquerda, construída durante o período da resistência à ditadura, no qual o fortalecimento de uma linguagem democrática passou a ser a palavra de ordem. Para Eugenia Palieraki, a esquerda chilena terminou por entregar ao MIR um papel "marginal y extranjero al campo político, puesto que parecía no recibir ni generar influencias sobre los otros partidos y movimientos" (PALIERAKI, 2008, p. 2).

Essa exclusão se verifica desde as referências a discussões estratégicas de grande porte, nas quais o MIR costumeiramente é colocado como um ator menor e relegado a um extremo que não teria peso efetivo nos debates, até pequenos episódios simbólicos que não aparecem em narrativas mais hegemônicas. Um exemplo é a frase atribuída a Allende, supostamente transmitida a Enríquez no dia do golpe: “Agora é tua vez, Miguel”, teria dito o presidente, num ato que significaria uma rendição ao caminho das armas como único viável a partir dali. Essa frase aparece extensamente numa literatura mirista, mas nunca é citada em alguns dos principais trabalhos sobre o 11 de setembro escritos por companheiros próximos ao presidente. ${ }^{13}$

Não há como estabelecer quais seriam as consequências de uma radicalização geral da UP, proposta mirista que não venceu dentro da esquerda. Ainda assim, é possível constatar o quanto vem sendo minimizada a influência do MIR sobre a coalizão governista, e a consideração real que parte da Unidad Popular teve por seguir elementos da tática apontada pelo grupo encabeçado por Miguel Enríquez.

Osvaldo Torres entende que a estratégia do MIR, buscando por muito tempo se diferenciar como uma opção "desde fora" da UP - tentando radicalizá-la a partir daí -, contribuiu para fazer a prova do tempo colocar o mirismo como uma figura antipática a Allende, com suas críticas ao governo se sobressaindo muito mais do que suas tentativas de aproximação (TORRES, 2012, p. 264). Isso fez com que o MIR, mesmo resistindo à ditadura e sendo dizimado por ela, não tenha conseguido "reivindicar la legitimad de su esfuerzo y sacrificio militante como para lograr um reconocimiento social expresado electoralmente o de otra forma" quando o regime militar se encerrou (TORRES, 2012, p. 273).

\footnotetext{
${ }^{13}$ A primeira menção a esse episódio aparece no livro de Carmen Castillo sobre os meses finais da vida de Miguel Enríquez (cf. CASTILLO, 1999, p. 25). Allende teria dito "Ahora es tu turno, Miguel”. Essa frase volta a aparecer em livros relacionados ao MIR, como o escrito pelo ex-mirista Patricio Rivas (2007, p. 37) e a biografia de Enríquez feita por Mario Amorós (2015, p. 243). Notavelmente, essa mensagem - que, segundo Amorós, teria sido transmitida a Miguel pela filha de Allende, Beatriz - não aparece em nenhum trabalho escrito por membros da UP que estiveram em La Moneda no 11 de setembro, como os de Joan Garcés (1993) ou de Óscar Soto (2008), e nem mesmo em uma das mais recentes biografias de Allende, a de Jesús Manuel Martínez (2009).
} 
Uma defesa da estratégia mirista se tornaria ainda mais difícil com o passar dos anos em função da política "el MIR no se asila", na qual a organização exigiu a permanência de seus militantes no Chile durante a ditadura - sob pena de serem expulsos como "desertores e covardes" (TORRES, 2012, p. 187) -, o que destruiu a cúpula do grupo e esvaziou seus quadros. Enquanto as lideranças da esquerda "tradicional" buscaram refúgio no exterior, chegando a participar da redemocratização após o fim do regime militar, o MIR perdeu a maior parte de seus dirigentes e teóricos, jamais recuperando sua antiga coesão interna ou sua relevância política. O próprio Miguel Enríquez, após mais de um ano na clandestinidade e sem nunca sair do país, seria morto em uma emboscada da polícia secreta de Pinochet em outubro de 1974.

\section{REFERÊNCIAS BIBLIOGRÁFICAS}

AGGIO, Alberto. Frente Popular, Radicalismo e Revolução Passiva no Chile. São Paulo: Annablume, 1999.

AGGIO, Alberto. Democracia e Socialismo. A experiência chilena. 2. ed. São Paulo: Annablume, 2002.

ALLENDE, Salvador. La Vía Chilena hacia el socialismo: Discursos. 3. ed. Madrid:

Fundamentos, 1998.

AMORÓS, Mario. Miguel Enríquez. Un nombre en las estrellas. 3. ed. Santiago de Chile:

Ediciones B, 2015.

ANDERSON, Sean K.; SLOAN, Stephen (ed.). Historical Dictionary of Terrorism. Lanham: Scarecrow Press, 2009.

BASSO, Carlos. La CIA en Chile. Santiago de Chile: Aguilar, 2013.

CASALS, Marcelo. El alba de una revolución. La izquierda y el proceso de construcción estratégica de la "vía chilena al socialismo". 1956-1970. Santiago de Chile: LOM, 2010.

CASTILLO, Carmen. Un día de octubre en Santiago. Santiago de Chile: LOM, 1999.

ENRÍQUEZ, Miguel. Jefe del MIR saca la cara (entrevista de Manuel Cabieses Donoso). Punto Final, Santiago de Chile, n. 53, 23 abr. 1968, p. 2-4.

ENRÍQUEZ, Miguel. Intervención en el foro organizado por el Secretariado Nacional de Cristianos por el Socialismo (nov. 1972). In: NARANJO, Pedro et al. (ed.). Miguel Enríquez. y el proyecto revolucionario en Chile. Discursos y documentos del Movimiento de Izquierda Revolucionaria, MIR. Santiago de Chile: LOM, 2004, p. 189-205.

ENRÍQUEZ, Miguel. ¡A desarrollar y fortalecer el poder popular! (12 jan. 1973). In: NARANJO, Pedro et al. (ed.). Miguel Enríquez y el proyecto revolucionario en Chile. Discursos y documentos del Movimiento de Izquierda Revolucionaria, MIR. Santiago de Chile: LOM, 2004, p. 207-219.

ENRÍQUEZ, Miguel. Análisis del resultado electoral, perspectivas y tareas (10 mar. 1973). In: NARANJO, Pedro et al. (ed.). Miguel Enríquez y el proyecto revolucionario en Chile. Discursos y documentos del Movimiento de Izquierda Revolucionaria, MIR. Santiago de Chile: LOM, 2004, p. 221-236.

ENRÍQUEZ, Miguel. Vivimos un momento histórico fundamental. Discurso en el Teatro Caupolicán, 17 jul. 1973. In: NARANJO, Pedro et al. (ed.), 2004. Miguel Enríquez y el 
proyecto revolucionario en Chile. Discursos y documentos del Movimiento de Izquierda Revolucionaria, MIR. Santiago de Chile: LOM, 2004, p. 261-269.

ENRÍQUEZ, Miguel. La táctica del MIR en el actual período (dez. 1973). In: NARANJO et al. (ed.). Miguel Enríquez y el proyecto revolucionario en Chile. Discursos y documentos del Movimiento de Izquierda Revolucionaria, MIR. Santiago de Chile: LOM, 2004, p. 277-323.

GARCÉS, Joan. Allende e as Armas da Politica. São Paulo: Scritta, 1993.

GONZÁLEZ, Mónica. La Conjura. Los mil y un días del golpe. Santiago de Chile: Catalonia, 2012.

MARAMBIO, Max. Las armas de ayer. Santiago de Chile: La Tercera, 2007.

MARTÍNEZ, Jesús Manuel. Salvador Allende. El Hombre que abría las alamedas. Santiago de Chile: Catalonia, 2009.

MIR. Declaración de Principios. Santiago de Chile: mimeo., 1965a.

MIR. Programa. Santiago de Chile: mimeo., 1965 b.

MONIZ BANDEIRA, Luiz Alberto. Fórmula para o caos: a derrubada de Salvador Allende (1970-1973). Rio de Janeiro: Civilização Brasileira, 2008.

NARANJO, Pedro. Introducción. In: . Miguel Enríquez y el proyecto revolucionario en Chile. Discursos y documentos del Movimiento de Izquierda Revolucionaria, MIR. Santiago de Chile: LOM, 2004, p. 15-28.

NERUDA, Pablo. Incitación al Nixonicidio y alabanza de la Revolución Chilena. 6. ed. Barcelona: Grijalbo, 1974.

PALIERAKI, Eugenia. La opción por las armas. Nueva izquierda revolucionaria y violencia política en Chile (1965-1970). Polis, Centro de Investigación Sociedad y Políticas Públicas, n. 19, p. 1-15, 2008. Disponível em <http://polis.revues.org/3882> Acesso em 15 mar. 2014.

PALIERAKI, Eugenia. ;La revolución ya viene! El MIR chileno en los años sesenta. Santiago de Chile: LOM, 2014.

PARTIDO COMUNISTA REVOLUCIONARIO. Una línea pequeño-burguesa y una línea proletaria en la revolución chilena (Santiago de Chile, 1967). In: FARÍAS, Víctor (ed.). La Izquierda Chilena (1969-1973): documentos para el estudio de su línea estratégica. Santiago de Chile: Centro de Estudios Públicos, 2000, p. 293-327.

PARTIDO SOCIALISTA. Las tesis del partido y la Declaración de El Arrayán (Documento confidencial interno, 1972). In: FARÍAS, Víctor (ed.). La Izquierda Chilena (1969-1973): documentos para el estudio de su línea estratégica. Santiago de Chile: Centro de Estudios Públicos, 2000, p. 1994-2006.

PASCAL ALLENDE, Andrés. El MIR chileno. Una experiencia revolucionaria. Rosario: Cucaña, 2003.

RIVAS, Patricio. Chile, un largo septiembre. Santiago de Chile: LOM, 2007.

SECRETARÍA GENERAL DE GOBIERNO. Libro Blanco del Cambio de Gobierno en Chile. 2. ed. Santiago de Chile: Lord Cochrane, 1973.

SECRETARIADO NACIONAL MIR. El MIR y el resultado electoral. Punto Final.

Documentos. Santiago de Chile, n. 115, 13 out. 1970, p. 1-12.

SOTO, Óscar. El último día de Salvador Allende. Barcelona: RBA, 2008.

TORRES, Osvaldo. Democracia y Lucha armada. MIR y MLN-Tupamaros. Santiago de Chile: Pehuén, 2012.

VIDAURRÁZAGA, Ignacio. Martes once, la primera resistencia. Santiago de Chile: LOM, 2013.

WINN, Peter. A Revolução Chilena. São Paulo: UNESP, 2010. 
ARTIGO ENVIADO EM: 31/01/2016

ARTIGO ACEITO PARA PUBLICAÇÃO EM: 16/06/2016 